\title{
PRODUCING FABRIC MASK AS AN EFFORT OF VIRUS TRANSMISSION PREVENTION AND OPTIMALIZING PEOPLE INCOME DURING COVID19 PANDEMIC (A CASE STUDY IN SUKARATU VILLAGE, CIKEUS SUB-DISTRICT, SERANG BANTEN).
}

\author{
Deni Sunaryo \\ Program Studi Manajemen Fakultas Ekonomi dan Bisnis Universitas Serang Raya \\ E-mail: denisunaryomm@gmail.com
}

\begin{abstract}
Making the mask functioned as a form of prevention in transmission of the virus, because the virus can be transmitted through the mouth, nose and eyes. The idea of making cloth masks stems from the lack of availability of masks and soaring mask prices in the market. Armed with one of the family members who have expertise in the field of sewing then came the idea to produce their own fabric masks with fabric materials that existed at first and then tried to market them at an appropriate price to optimize revenue in the covid-19 pandemic. fabric mask material used is cotton with a variety of funny motives, in addition to the function of health and aesthetic functions to increase people's interest in wearing cloth masks.
\end{abstract}

Keywords : Cloth Masks, Optimizing Income, Prevention of Virus Transmission, Covid-19 Pandemic

\begin{abstract}
Abstrak
Pembuatan masker difungsikan sebagai salah satu bentuk pencegahan dalam penularan virus, karena virus dapat tertular melalui mulut, hidung dan mata. Ide pembuatan masker kain ini bermula dari minimnya ketersediaan masker serta melonjaknya harga masker dipasaran. Berbekal dari salah satu anggota keluarga yang mempunyai keahlian dibidang menjahit lalu munculah ide untuk memproduksi masker kain sendiri dengan bahan-bahan kain yang ada pada awalnya lalu mencoba untuk memasarkannya dengan harga yang sesuai untuk mengoptimalkan pendapatan di masa pandemi covid-19 ini. bahan masker kain yang digunakan yaitu bahan katun dengan berbagai macam motif yang lucu-lucu, selain fungsi untuk kesehatan adapula fungsi estetika untuk menambah minat masyarakat dalam memakai masker kain.
\end{abstract}

Kata Kunci: Masker Kain, Mengoptimalkan Pendapatan, Pencegahan Penularan Virus, Pandemi Covid-19

\section{Article Info:}

Received 31 May 2020

Accepted 15 April 2020

Available online 31 Agustus 2020

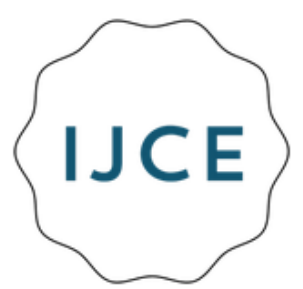




\section{PENDAHULUAN}

Beberapa waktu lalu masyarakat berbondong - bondong memborong masker untuk disimpan dan digunakan sebagai upaya pencegahan wabah virus Covid-19 atau disebut juga virus corona. Hal tersebut menjadi salah satu penyebab kelangkaan masker di Indonesia. Kelangkaan membuat masyarakat yang membutuhkan masker seperti orang sakit, orang yang merawat orang sakit dan tenaga kesehatan kesulitan untuk mendapatkan alat pelindung hidung serta mulut. Meski demikian, dalam situasi seperti ini muncul opsi baru penggunaan masker kain untuk menggantikan masker bedah yaitu masker berbahan dasar kain dapat dijadikan alternatif untuk mencegah penularan virus. masker kain dapat menjadi pilihan ketimbang tak menggunakan masker sama sekali. Alat Pelindung Diri (APD) adalah salah satu upaya untuk melindungi sebagian atau seluruh tubuhnya dari potensi bahaya. APD terhadap debu dan udara yang terkontaminasi polutan salah satunya berupa masker, yang berfungsi untuk melindungi debu atau partikel yang masuk ke dalam pernapasan, dapat berupa kain dengan ukuran poripori tertentu (A.M. Sungen Budiono, dkk., 2003:332). Masker adalah APD yang paling umum digunakan di indonesia dilihat dari sebelumnya masker kain digunakan untuk para pengendara sepeda motor tersedia secara umum dan masker sudah menjadi keperluan bahkan hal wajib yang dimiliki semua orang selama pandemi ini. Seperti yang sudah kamu ketahui, bahwa masker medis sudah menjadi barang yang langka di tengah pandemi COVID-19 ini. Masker medis yang mayoritas berwarna hijau, masker N95 dan sejenisnya sudah sulit ditemukan di pasaran. Kalaupun ada harganya juga terbilang mahal. Bahkan saat ini masker medis dihargai sekitar Rp15,000 untuk satu lembar, padahal dengan harga segitu, sebelumnya kita bisa mendapatkan 3-5 masker.

Memang, dalam hukum ekonomi hal ini terbilang wajar. Saat permintaan akan suatu barang naik, persediaan barang akan semakin menurun. Menurunnya barang tersebut, akan mengakibatkan kelangkaan sehingga harga akan naik. Dengan adanya hal ini, tentu saja peluang bisnis masker kain semakin tinggi. Tak heran kalau di beberapa industri konvesksi sudah banyak produsen memproduksi masker kain karena permintaannya cukup besar. Bahkan, banyak juga yang pebisnis yang mengalihkan bisnisnya menjadi bisnis masker kain. Nampaknya memperoduksi masker sendiri itu sangatlah bagus, berbekal dari salah satu anggota keluarga yaitu tante saya sendiri Nita (51 tahun) yang sudah memiliki keahlian dalam menjahit karena sebelumnya sudah mempunyai konveksi pembuatan sprei serta badcover dan selama masa pandemi covid-19 mulai mencoba untuk memproduksi masker kain. Bahan yang digunakan untuk pembuatan masker kain ini menggunakan bahan katun dengan kain-kain yang bermacam-macam motifnya dan bentuk penggunaan yang sesuai dengan minat para konsumen. salah satu motifnya bermotif bunga-bunga, animasi, serta polkadot (bulat-bulat) dan untuk bentuk penggunaanya masker dibuat untuk penggunaan berhijab dengan tali yang fleksibel bisa diatur sendiri dan bentuk untuk kaum pria yang hanya dipasangkan ditelinga saja.

\section{METODE}

Program Pengabdian yang dilaksanakan di masa pandemi covid-19 ini berjudul "Pembuatan Masker Kain Sebagai Pencegahan Penularan Virus Serta Mengoptimalkan Pendapatan Di Masa Pandemi Covid-19 Bagi Masyarakat Di Desa Sukaratu Kecamatan Cikeusal Serang-Banten" dilaksanakan dengan menggunakan:

\section{Metode Kualitatif}

Menurut Denzin \& Linclon (1994) menyatakan bahwa penelitian kualitatif adalah penelitian yang mengguanakan latar alamiah dengan maksud menafsirkan fenomena yang terjadi dan dilakukan dengan jalan melibatkan berbagai metode yang ada. Erickson (1968) menyatakan bahwa penelitian kualitatif berusaha untuk menemukan dan menggambarkan secara naratif kegiatan yang dilakukan dan dampak dari tindakan yang dilakukan terhadap 
kehidupan mereka. Pendekatan kualitatif dapat digunakan apabila ingin melihat dan mengungkapkan suatu keadaan maupun suatu objek dalam konteksnya; menemukan makna (meaning) atau pemahaman yang mendalam tentang suatu masalah yang dihadapi, yang tampak dalam bentuk data kualitatif, baik berupa gambaran, kata maupun kejadian.

Menurut Bogdan dan Biklen (1982: 27-29), karakteristik penelitian kualitatif yaitu; (1) Dilakukan pada kondisi yang alamiah, (sebagai lawannya adalah eksperimen). Langsung ke sumber data dan penelitian adalah instrument kunci, (2) Penelitian kualitatif lebih bersifat deskriptif. Data yang terkumpul berbentuk kata-kata atau gambar, sehingga tidak menekankan pada angka, (3) Penelitian kualitatif lebih menekankan pada proses daripada produk atau outcome, (4) Penelitian kualitatif melakukan analisis data secara induktif, dan (5) Penelitian kualitatif lebih menekankan makna (data dibalik yang teramati).

Metode pendekatan kualitatif sangatlah cocok digunakan karena pembuatan masker kain bermuncul dari melihat serta mengungkapkan peristiwa atau keadaan yang terjadi saat ini, dengan munculnya virus corona (covid-19) seluruh masyarakat diwajibkan untuk menggunakan masker. masker kain merupakan salah satu cara untuk mencegah penularan virus. Awal pembuatan masker kain ini bertujuan untuk mensupplay ketersedian masker agar tidak terlalu lama mengalami kelangkaan serta harga jual masker dipasaran yang memainkan harga diluar dari harga pasaran yang sebelumnya. Meski masker kain tidak seefektif masker N95 atau masker lain yang tersedia di apotik (biasanya tersedia dengan merek Sensi, Nexcare atau Altamed) setidaknya menggunakan masker kain cukup bermanfaat untuk meminimalisir paparan terhadap droplet virus corona dalam aktivitas sehari-hari di luar ruangan, sehingga kebutuhan masyarakat akan masker kain sangat meningkat.

2. Penelitian Tindakan

Tugas utama penelitian tindakan adalah menghasilkan informasi dan pengetahuan, serta keterampilan baru yang dapat digunakan secara langsung kepada sekelompok orang melalui penelitian, dan juga dimaksudkan untuk memberikan penerangan pada sekelompok subjek peneliti, memotivasi mereka untuk menggunakan informasi yang mereka dapat melalui penelitian. Menurut Blum (Cohen Manion, 1980), Penelitian tindakan sangat bermanfaat dalam upaya peningkatan dan perbaikan. Rapoport (1970, dikutip oleh Hopkins, 2008: 47) menyatakan bahwa : Aims to contribute both to the practical concerns of people in an immediate problematic situation and the goals of social joint collaboration within a mutually acceptable ethical framework (Penelitian tindakan ditunjukan untuk memberikan kontribusi pada pemecahan masalah praktis dalam situasi problematik yang mendesak pada pencapaian tujuan ilmu-ilmu sosial melalui kolaborasi patungan dalam kerangka kerja etis yang saling dapat menerima).

Langkah-langkah penelitian tindakan:

1) Mengidentifikasi area yang akan dijadikan masalah penelitian

a. Dipertengahan februari indonesia mulai dicemaskan dengan munculmya virus corona (Covid-19) dimana seluruh masyarakat mulai dihimbau untuk menggunakan masker ketika berpergian untuk melindungi diri dari penularan virus corona termasuk di wilayah kota Serang-Banten.

b. Dari bulan maret sampai dengan april banyak pelaku bisnis yang menjualkan masker karena keterbatasan tersediannya masker pelaku bisnis tersebut banyak yang menetapkan harga masker lebih mahal dibandingkan dengan harga masker ketika sebelum adanya pandemi virus ini. karena minimnya ketersediaan masker dan melonjaknya harga di pasaran munculah ide untuk membuat masker sendiri dari bahan kain dan kain yang digunakan saat itu adalah kain dari sisa-sisa pembuatan sprei (sisa dari konveksi).

c. Pembuatan maker bermula difungsikan sebagai konsumsi pribadi dan melihat peluang bisnis ditengah pandemi untuk berjualan masker kain dengan harga yang standar. 
2) Memformulasikan rencana tindakan

a. Masker kain merupakan salah satu alat pelindung diri (APD) sebagai salah satu barang yang dapat mencegah penularan virus melalui hidung atau mulut.

b. Dengan memproduksi masker kain sendiri membuat ketersediaanya masker untuk anggota keluarga.

c. Masker kain yang digunakan adalah dengan berbahan katun jepang.

3) Tindakan dan pengamatan

Tindakan yang dilakukan adalah setelah masker terproduksi kemudian mulai memasarkannya dengan harga yang standar. konsep nya untung sedikit asalkan permintaanya banyak dengan memasarkannya memalui via whatsapp, shopee, dan instagram.

4) Evaluasi Tindakan

Selain mudah dibuat sendiri, penggunaan masker kain ini juga dapat dicuci dan dipakai kembali sehingga bisa lebih hemat. Namun sebenarnya, penggunaan masker kain ini juga mempunyai sisi kelebihan dan kekurangan tersendiri.

a. Kelebihan:

(1) Dapat digunakan untuk menahan droplet

Sama halnya dengan masker pada umumnya, kelebihan masker kain yang pertama adalah mampu menahan droplet atau air percikan batuk atau bersin yang bisa ditularkan penderita Covid-19 ke orang lain. Kemampuan ini sempat diragukan oleh banyak orang.Tetapi penggunaan masker kain terbukti dapat menahan droplet atau cairan yang terdapat virus. Meskipun demikian, pemakaian masker kain ini mempunyai aturan tersendiri. Anda disarankan untuk segera mengganti masker yang lebih bersih setelah pemakaian selama 3 jam. Untuk itu memang dianjurkan memiliki beberapa potong masker kain untuk persediaan. Sehingga masker tersebut dapat digunakan secara berganti-ganti untuk tetap menjaga kebersihannya.

(2) Harga Lebih Terjangkau

Penggunaan masker kain juga memiliki kelebihan lain yaitu harganya yang lebih terjangkau. Hal ini jelas jika dibandingkan penjualan masker bedah yang kini mencapai 300.000 rupiah per kotaknya. Sedangkan masker kain sendiri bisa didapatkan dengan harga di bawah 10.000 rupiah per lembarnya. Masker kain ini juga masih mudah ditemui di pasaran.

(3) Bisa Dicuci dan Dipakai Kembali

Bukan hanya harganya yang murah dan mudah dibuat, penggunaan masker kain juga dapat terbilang hemat. Bukan tanpa alasan, pemakaian masker kain bisa dicuci dan dipakai kembali sehingga tidak terhindar dari pemakaian yang terlalu boros. Tidak perlu khawatir higienitasnya, masker kain ini bisa kembali bersih dan steril setelah dicuci dengan baik. Cara mencucinya pun tidak rumit, sama seperti mencuci bahan kain pada umumnya. Jadi jika mulai merasa lelah mencari stok masker yang tidak kunjung ada, masker kain ini bisa menjadi pilihan.

(4) Mengurangi Sampah

Penggunaannya yang hemat dan dapat dipakai berulang-ulang, membuat penggunaan masker kain ini membantu mengurangi sampah yang ada. Penggunaan masker bedah sekali pakai pada umumnya memang harus segera dibuang setelah pemakaian. Hal ini tentu saja menyebabkan banyaknya sampah masker yang menumpuk di tempat pembuangan. Apalagi jika masker sekali pakai ini digunakan hampir semua orang. Penggunaan masker kain yang dapat dicuci dan dipakai ulang ini merupakan rekomendasi baik untuk mengurangi sampah yang ada. Memiliki masker kain dalam jumlah yang cukup banyak pun tidak menjadi masalah, karena masih dapat dipakai dalam jangka panjang. 
b. Kelemahan:

(1) Tidak Direkomendasikan Bagi Petugas Medis

Dari semua kelebihan masker kain yang ada, terdapat satu kekurangan yang tidak boleh diabaikan. Di mana penggunaan masker kain tidak direkomendasikan untuk petugas medis yang menangani langsung dengan pasien Covid-19. Penggunaan masker kain ini justru semakin memperbesar peluang penularan virus corona jika dipakai oleh petugas medis. Bisa jadi virus tersebut menempel dan bertahan pada masker kain tersebut. Bagaimanapun juga, masker bedah mempunyai kemampuan 3 kali lebih efektif untuk mencegah penularan virus corona dibandingkan masker kain. Masker kain dinilai tidak mampu menyaring partikel kecil virus sehingga penggunaannya membahayakan tenaga medis.

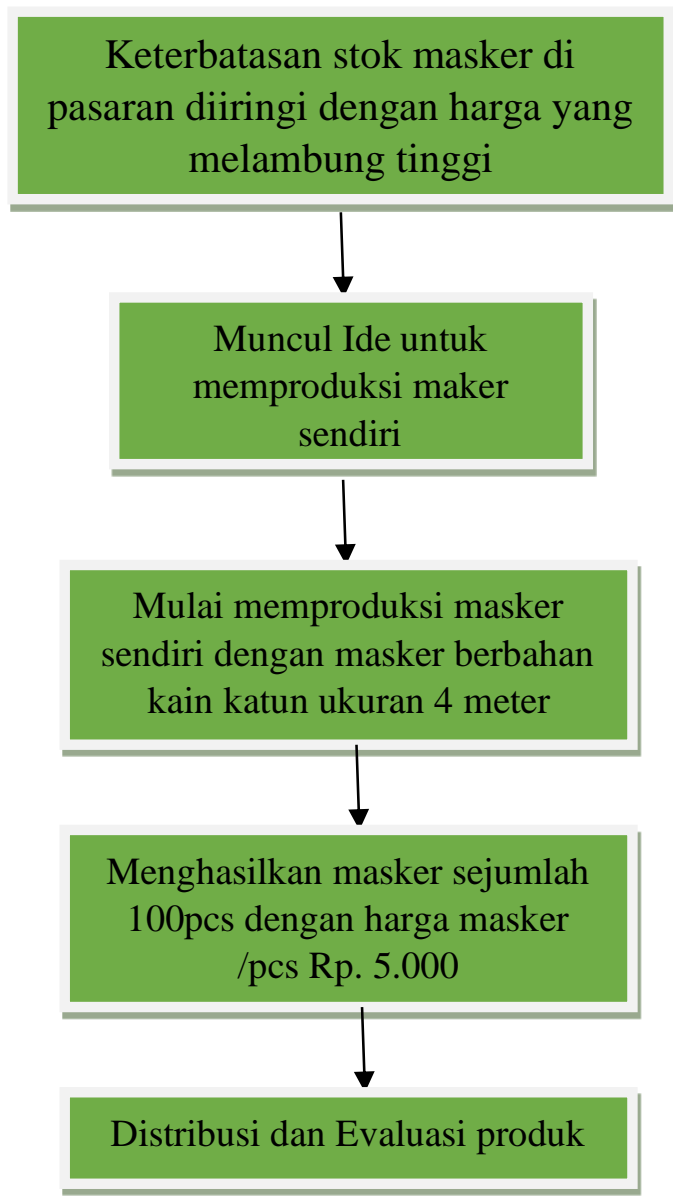

Gambar 1. Alur Kegiatan

\section{HASIL DAN PEMBAHASAN}

Kegiatan pembuatan produk masker kain yang bertujuan untuk mencegah penularan virus melalui hidung dan mulut. Bahan yang digunakan adalah dengan menggunakan katun jepang berukuran 4 meter untuk mendaptkan masker sejumlah 100pcs masker. Ada 4 macam model masker yang digunakan seperti: 
Indonesian Journal of Community Empowerment (IJCE)

Volume 01 Nomor 01 (August) 2020

1. Model tali berada di tepi kanan dan kiri

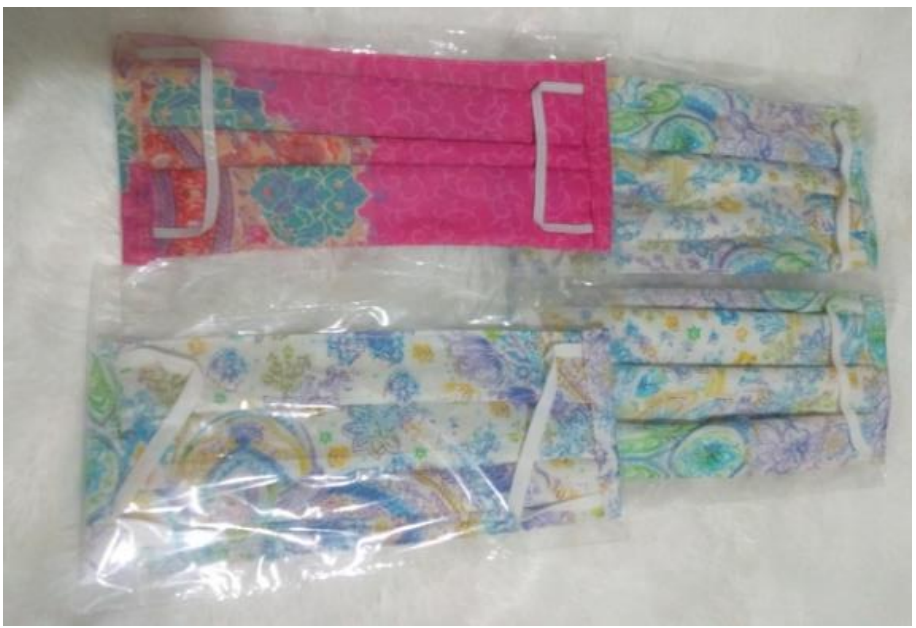

Gambar 2. Model Pertama

2. Model dengan 1 layer

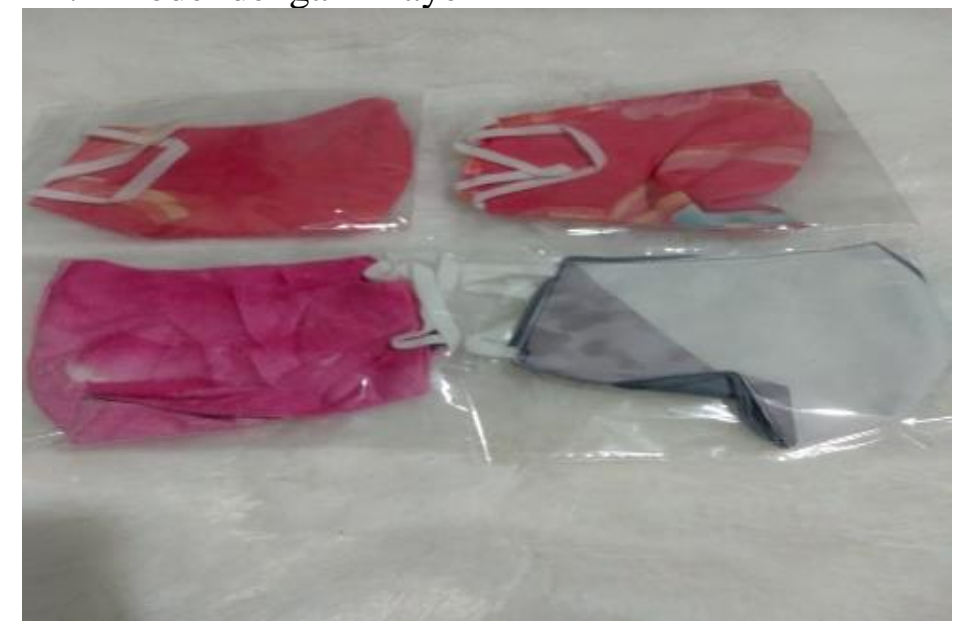

Gambar 3. Model face 1 layer

3. Model tali fleksibel/ khusus untuk hijab

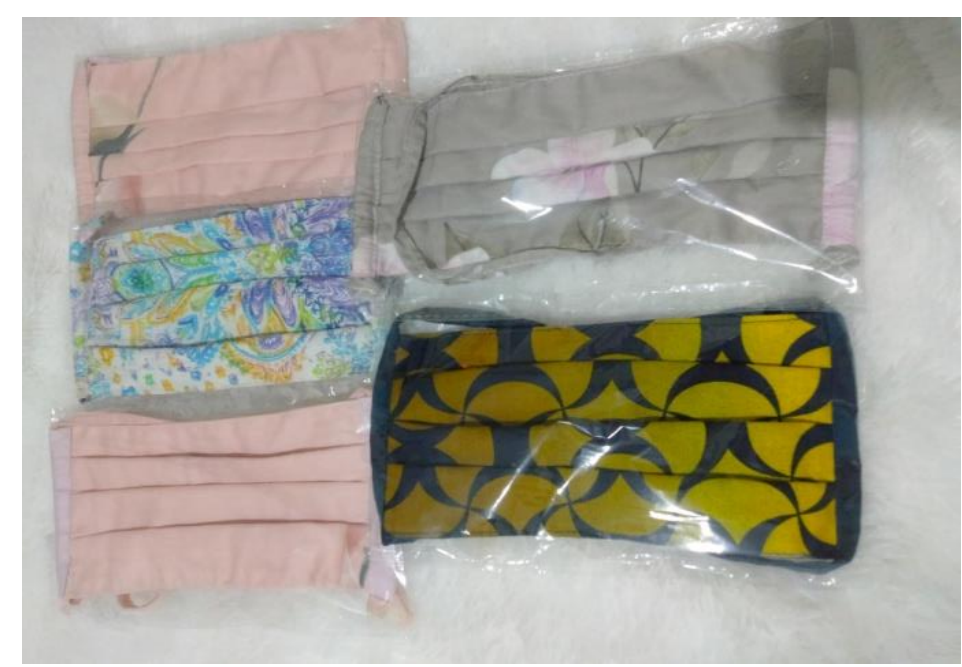

Gambar 4. Model ketiga dengan tali bisa di atur sesuai keinginan 
4. Model tali silang

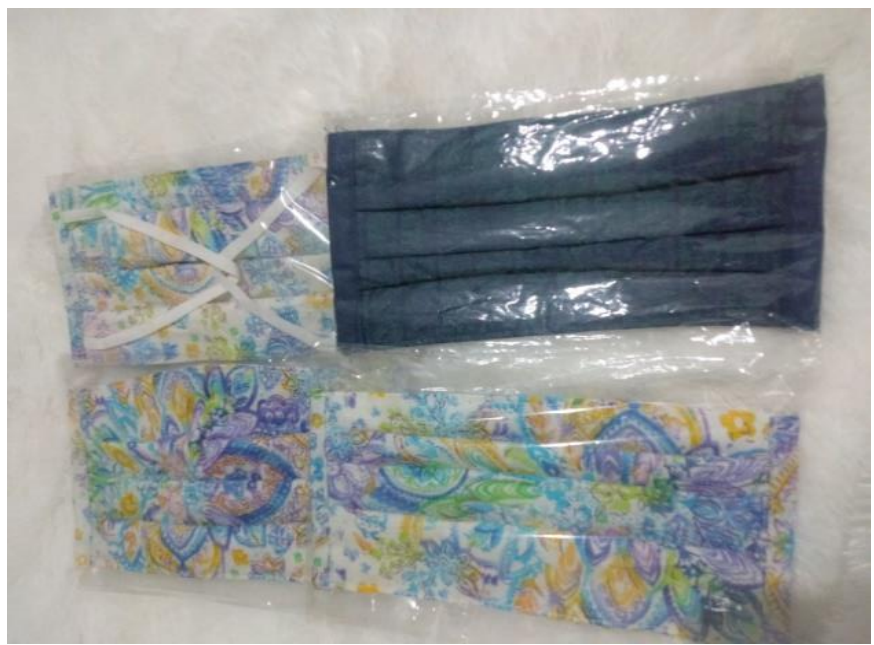

Gambar 5. Model tali silang

Itulah 4 model masker yang diproduksi dengan berbagai macam motif untuk menambah nilai estetika di masker tersebut selain nilai fungsi yang didapatkan. Adapun bahan-bahan dan alat yang digunakan untuk membuat masker kain:

1. Mesin Jahit

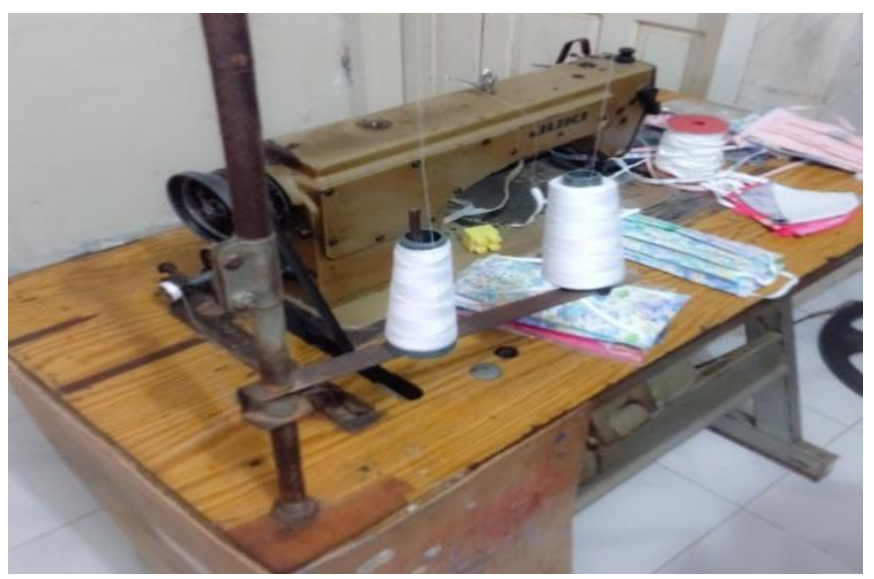

Gambar 6. Mesin Jahit

2. Kain Katun Jepang

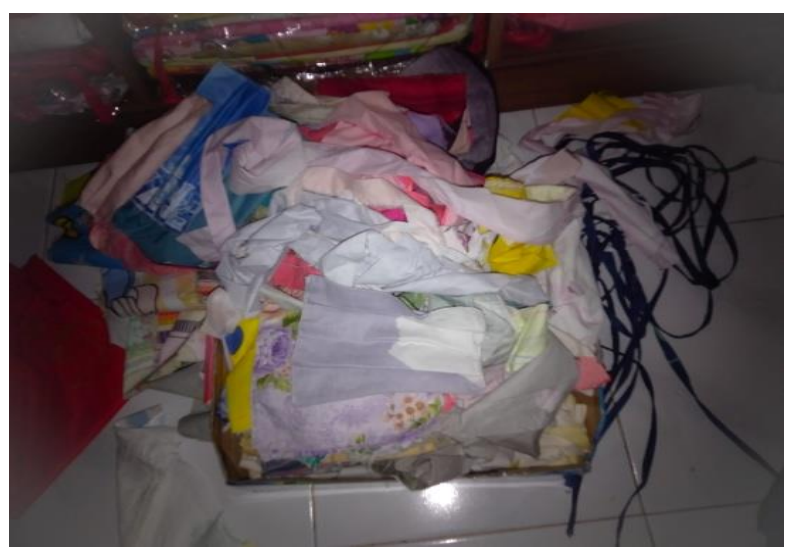

Gambar 7. Kain Katun 


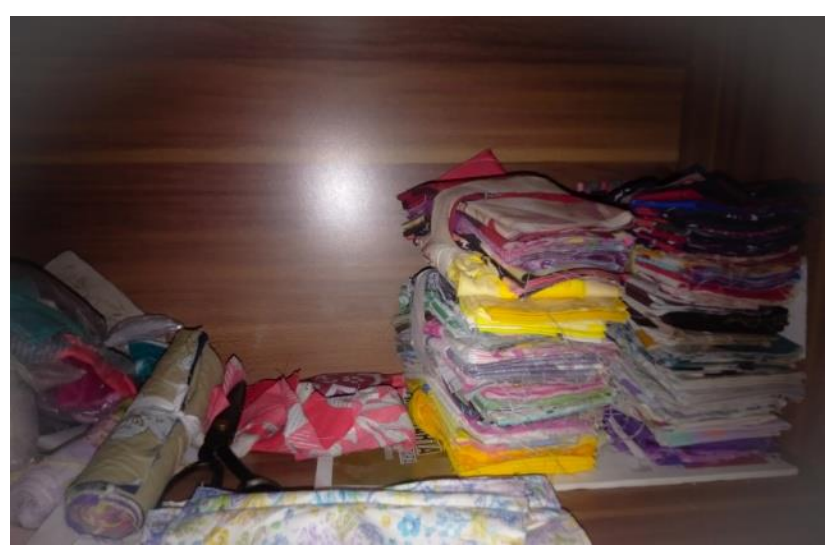

Gambar 8. Bahan yang sudah dibentuk

3. Tali/Karet Elastis

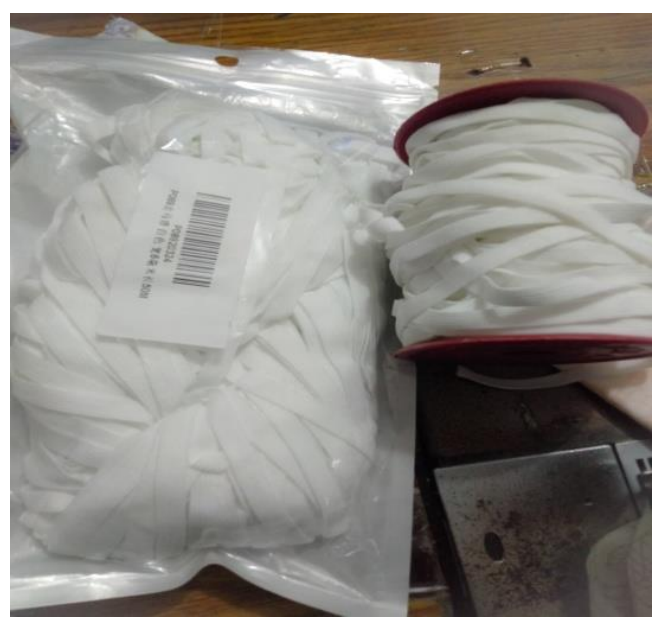

Gambar 9. Tali Elastis

4. Benang Jahit

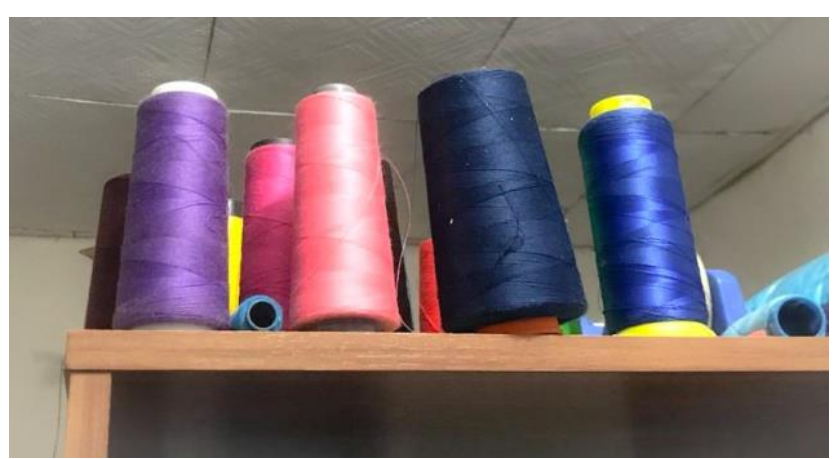

Gambar 10. Benang

5. Plastik packing

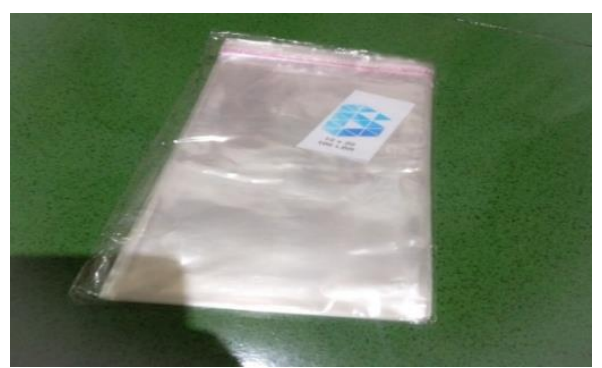

Gambar 11. Plastik 
Langkah-langkah pembuatan masker kain:

1. Pola kain sesuai dengan bentuk masker yang diinginkan contoh ukuran pola kain yang dibuat adalah $18 \mathrm{~cm} \times 9 \mathrm{~cm}$

2. Potong kain yang sudah di pola kemudian jahit tepinya agar rapih dan tambahkan tali/ karet elastis

3. Setelah masker selsai dijahit kemudian setrika masker agar lebih rapih dan steril

4. Setelah di setrika masukan kedalam pelastik pengemas

5. Masker siap di distribusikan.

Biaya yang diperlukan untuk bahan dasar pembuatan masker kain sangatlah terjangkau tabel 1 berikut menjelaskan analisa usaha produksi masker kain:

\section{A. Aktiva Tetap}

Tabel 1. Aktiva Tetap

\begin{tabular}{llllll}
\hline Keterangan & Unit & Rp/Unit & Nilai & $\begin{array}{l}\text { Umur } \\
\text { Ekonomis }\end{array}$ & Penyusutan \\
\hline Gunting & 1 & 10.000 & 10.000 & 2 & 14 \\
Nilai penyusutan per1x produksi & & & 14 \\
\hline
\end{tabular}

\section{B. Biaya Variabel}

Tabel 2. Biaya Variabel

\begin{tabular}{lclc}
\hline \multicolumn{1}{c}{ Ket } & Unit & Rp/Unit & Nilai \\
\hline $\begin{array}{l}\text { Kain } \\
\text { Katun }\end{array}$ & 4 Meter & 55.000 & 220.000 \\
$\begin{array}{l}\text { Karet } \\
\text { Elastis }\end{array}$ & 1 Roll & 30.000 & 30.000 \\
$\begin{array}{l}\text { Pelastik } \\
\text { packing } \\
\text { Benang }\end{array}$ & 1 pack & 6.000 & 6.000 \\
& JUMLAH & 20.000 & 20.000 \\
& & & 276.000 \\
\hline
\end{tabular}

\section{Total Cost}

$$
\begin{aligned}
\text { Total Cost } & =\text { Biaya Tetap }+ \text { Biaya Variabel } \\
& =14+276.000 \\
& =276.014
\end{aligned}
$$

\section{Revenue}

Revenue dengan harga jual Rp. 5000/Masker adalah 500.000 untuk setiap masker yang terjual total 100 masker dengam modal 276.014 dan pendapatan 500.000 per100 masker jadi:

$$
\begin{aligned}
& =500.000-276.014 \\
& =223.986 \text { (untung } / 100 \text { masker) }
\end{aligned}
$$


$=223.986: 100$ masker

$=2.239 /$ masker

Jadi keuntungan /masker adalah Rp.2.239

Pada tabel 1 dan 2 menjelaskan analisa usaha produksi masker kain alternatif pada masa pandemi covid-19 di Kota Serang Banten. Pada dasarnya masker kain dapat dijual dengan variasi harga yang berbeda-beda asalkan harga yang ditetapkan tidak jauh melebihi dari harga yang ditawarkan, analisa tersebut dihitung dalam satu kali produksi yaitu 100 masker kain bermotif dalam 2 hari dengan harga penjualan Rp. 5000/masker.Pemasaran masker kain ini dapat dipasarkian secara langsung kepada konsumen melalui tetangga yang berjualan online shop, memasanag barang di shopee berjualan dengan promosi dari whatsapp dan instagram. Dalam bisnis masker kain ini tidak ditujukan untuk untung yang banyak tapi bagaimana caranya barang banyak laku terjual dan banyak yang minati.

\section{KESIMPULAN DAN SARAN}

Dari Pelaksanaan pembuatan masker kain ini dalam rangka pencegahan penularan virus corona (covid-19) serta untuk mengoptimalkan pendapatan di tengah-tengah masa pandemi ini dapat disimpulkan bahwa:

1. Masker kain adalah masker alternatif untuk pencegahan penularan virus yang dapat tertular melalui hidung atau mulut

2. Adapun kelebihan dari penggunaan masker kain ini adalah:

a. Dapat digunakan untuk menahan droplet

b. Harga lebih terjangkau

c. Bisa dicuci dan dipakai kembali

d. Mengurangi sampah

3. Masker yang diproduksi ada 4 model ( Model tali ditepi kanan kiri, Model 1 layer masker, model tali fleksibel/untuk wanita berhijab, dan model tali silang.

4. Berbisnis masker kain merupakan peluang yang sangat bagus ditengah kondisi pandemi covid-19 ini

5. Metode pelaksanaan yang digunakan ada 2 yaitu metode pendekatan kualitatif dan penelitian tindakan.

\section{REFERENSI}

[1] Achmad, Nur. 2015. Kewirausahaan: Suatu Alternatif Lain Menuju Kesuksesan. Surakarta: BPK FEB UMS.

[2] Anggito Albi dan Setiawan Johan. 2018. Metodologi Penelitian Kualitatif. Sukabumi: Jejak Publisher

[3] Drucker.Peter.F.1993. Inovasi Dan Kewiraswastaan. Jakarta: Erlangga.

[4] Kasmir. 2010. Kewirausahaan. Jakarta: PT Raja Grafindo Persada

[5] Yusuf Muri. 2016. Metode Penelitian. Kuantitatif, Kualitatif \& Penelitian Gabungan. Jakarta: Prenda Media

[6] https://www.merdeka.com/sumut/5-kelebihan-dan-kekurangan-masker-kain-alternatifkelangkaan-selama-pandemi-corona-kln.html 